BEBINA MILOVANOVIĆ

Institute of Archaeology,

Belgrade, Serbia

bebina27@yahoo.com

MILICA MARJANOVIĆ

Institute of Archaeology,

Belgrade, Serbia

IVANA KOSANOVIĆ

Institute of Archaeology,

Belgrade, Serbia
904:739.5"652"(497.11)

904:686.7"652"(497.11)

COBISS.SR-ID 228045068

Original research article

Received: December $7^{\text {th }} 2015$

Accepted: June $20^{\text {th }} 2016$

\title{
A NEW FIND OF LEAD MIRROR FRAMES FROM RIT (VIMINACIUM)
}

\begin{abstract}
Eleven miniature lead mirror frames were discovered during the protective archaeological excavations of Viminacium in 2015, at the Rit site. The frames were found in a ditch probably used at first as a canal for drainage and was filled with waste material during the cleaning of the necropolis afterwards. Some of the mirrors represent a unique find, since few of these types have been found on the territory of Viminacium so far, and the only analogies are the ones from the Hungarian National Museum in Budapest. These finds confirm the widespread opinion about these mirrors not having been used as cosmetic or toilet articles, but as cult/apotropaic objects.
\end{abstract}

\section{KEYWORDS: LEAD, MINIATURE MIRROR FRAMES, RIT, VIMINACIUM, APOTROPAIC OBJECTS.}

\section{INTRODUCTION ${ }^{1}$}

During the protective archaeological excavations of Viminacium in 2015, at the Rit site, eleven lead miniature mirror frames were found. This site was endangered by the expansion of the strip coal mine, Drmno. Rit is located north-east of the city of Viminacium. At this site, four villas and several parts of a necropolis (possibly more than one) have been excavated so far. The necropolis is located in a west-east directon, along the road which

1 This article resulted from the project: IRS - Viminacium, Roman city and military legionary camp - research of the material and non-material culture of inhabitants by using the modern technologies of remote detection, geophysics, GIS, digitalisation and $3 D$ visualisation (no. 47018), funded by the Ministry of Education, Science and Technological Development of the Republic of Serbia. led from Viminacium to Lederata (Danković, Petaković 2013, 60-63; Mikić et al. 2006, 21-26; Milovanović et al. in print; Redžić et al. 2012, 66-70; Redžić et al. in print). Many pits were found at the necropolis, and some of them were used first for the extraction of clay, and later as waste pits, but some of them were probably primarily used as waste pits for the clean-up of the cemetery. A few ditches for the accumulation of water from this area were also investigated and, after losing their primary role, they were filled with the discarded material from the cemetery or from the residential objects nearby. Recent archaeological excavations have shown that these residential objects were erected during the III century, and they were followed by the necropolis spreading towards the north-east, probably along the road to Lederata. 
Settling in this area stopped during the IV century, when the drainage system had also obviously stopped functioning, flooding the area and turning it into a reed-patch with swamps (Danković, Petaković 2013, 63).

During 2015, besides the investigated part of the necropolis, a section of a ditch was discovered and excavated. The ditch extended in an east-west direction, and the graves of the cremated and inhumed deceased are located south of the ditch. The primary function of this ditch and its definite dimensions could not be determined. The ditch was investigated through five trenches in which it could be followed diagonally, and it has been investigated to a length of $25.65 \mathrm{~m}$ and a maximum width of $2.20 \mathrm{~m}$. At a depth of between 0.35 and $0.5 \mathrm{~m}$ in this ditch, eleven miniature lead mirrors were found, all of them located in an area of approximately $1 \mathrm{~m}^{2}$. Besides pottery sherds, animal bones, brick and schist fragments, there have been found: a bronze needle with a head in the form of an axe, the bottom of a pottery lamp with a NERI stamp and a bronze coin from the middle of the III century (Valerianus, Provincia Dacia).

It is obvious that the ditch is connected to the cemetery, especially because of the position of the graves following the direction of the ditch. The ditch could have been the border of the necropolis, but also a canal for drainage. Over the course of time, the ditch was filled with the waste material during the cleaning of the cemetery. The finds of coins from the necropolis layer, as well as from the graves, suggest that the necropolis was used in the period of the second half of the II century and in the III century, the latest coins being from the time of Maximianus and Diocletianus.

\section{LEAD MIRROR FRAMES FROM RIT}

Eleven mirrors found in a ditch at the site of Rit belong to the miniature-mirror type, with a reflecting surface made of glass. The mirror frames are made of lead, cast in a bipartite mould. All of them are circular in shape, with leaves on top, while some specimens have a vertical handle, which can have a triangular widening or side strengthening in the lower part of the frame, preserved. This triangular widening could also be the scraps left from the casting process. The Rit specimens do not have preserved glass in the centre; on the back they have a circular relief around the opening for the mirror hole.

These mirrors can be divided into five groups, based on the frame decoration.

Five mirror frames (Cat. Nos. 1-5) have a surface divided into three concentric circular sections, two inner sections filled with radial lines, and the external one decorated with a wavy (stylised zigzag) line. Analogous to these frames are the specimens from the collection of the Hungarian National Museum. These three frames have the identical decoration as the Rit finds but, due to their unknown provenance, we remain deprived of information regarding their dating (Bózsa, Szabó, 2013: 67, II.3.16, Cat. No. 108-110). This type of mirror can be connected with the mirrors from Pincum (Спасић 1996, 54, кат. бр. 35) and Sucidava (Tudor 1959, 417, type VI, Fig. 1/7, Fig. 2/9-11), which have sharper zig-zag lines; these specimens were dated from the second half of the II to the III century.

One mirror frame (Cat. No. 6) is divided into three annular sections with sloping radial lines pointing in alternating directions. Analogies can be found in the collection of the Hungarian National Museum, but unfortunately they do not contain any additional information (Bózsa, Szabó, 2013: 64, II.3.9a. Cat. No. 85-95, II.3.9b. Cat. No. 90-94). The frame decorated with a fish-bone motif in the middle and radial lines around the outer edge (Cat. No. 7) can be classified as the same type. The closest analogy for this specimen is the mirror from Sucidava (Tudor 1959, 427, Fig. 1/5, Cat. No. 6).

One mirror specimen (Cat. No. 8) has a simply decorated frame with relief radial lines. Analogies 
can be found at the Čair site, Viminacium, (Спасић 1996, 55, кат. бр. 37, second half of the II and the III century), as well as in the collection of the Hungarian National Museum (Bózsa, Szabó, 2013: 61, II.3.1. Cat. No. 53-57; 64, II.3.4 Cat. No. 60-68).

Two mirror frames are decorated with floral motifs (Cat. Nos. 9-10), namely spiral vines and granules. Analogies for these samples are numerous, due to the spread of the vine motif in the Roman period. A direct analogy is an example from the Hungarian National Museum, of unknown origin (Bózsa, Szabó, 2013: 81, II.3.69. Cat. No. 504).

An interesting and unique find is the mirror frame decorated with alternately distributed relief circles and rhomboids, which contain granules in the middle (Cat. No. 11); the space between the rhomboids and circles is also filled with single granules. The bottom of the frame and the handle are also decorated with a combination of geometric motifs and granules. This specimen has no direct analogies, but there is a certain similarity with the mirror from Viminacium (Спасић 1996, 33-34, 50-51, кат. бр. 19).

\section{DISCUSSION}

A cheap and simple technological process of lead production was crucial for its widespread use in the ancient period, and its specific features, such as its colour, weight and poisonous properties, gave certain lead objects magical and, above all, cult status. The curse tables, Danubian horsemen icons, deity figurines, but also miniature mirror frames, all belong to the category of cult objects made mostly, or exclusively, of lead, and rarely of any other material (Milovanović 2008, 5-8).

There are many different opinions concerning the usage of miniature lead mirrors in the Roman period. The ones of a rectangular shape might have been attached to the inner part of the lid of boxes for storing medical and cosmetic instruments (Kouzov 2002, 97) or they could have simply been kept in leather cases (Крунић 2000,
11). Also, there are opinions that miniature lead mirrors were some sort of souvenir, or that they were used as fetishes in cults and rituals (Kouzov 2002, 97). These miniature mirrors were often found in shrines dedicated to female deities, probably as votive gifts (Barrata 2009a, 67-74), or they were objects used in funerary cults (Bózsa 2012, 39) etc.

The miniature dimensions of the reflecting surface on these lead mirrors (the glass itself is usually not bigger than $2 \mathrm{~cm}$ in diameter) diminish their practical function. The greatest attention is paid to the richly decorated frame, so we could rather assume their cult use, especially considering the various symbolic motifs on them. The examples of mirrors with the inscriptions related to good luck (Спасић 1996, 59; Величковић 1959, 59-60; Косановић 2015, 224-225), erotic or love messages (Nemeth, Szabo 2010; Спасић 1996, 59) or containing dedications to the goddesses and women in general (Nemeth, Szabo 2010, 101-113; Barrata 2009a, 67-74; Barrata 2009b, 432-454; Sobin 2000, 175) confirm the apotropaic character of these items.

Mirrors were attested as objects of divination and magical rituals in the written sources of the classical period. For example, in the temple of Demeter in Patras, the future was foreseen by dipping a mirror into water. Large mirrors fixed at the entrance of the Despoina sanctuary in Lycosura gave interesting visions. In ancient Greek, divination with reflective surfaces was called catoptromancy. Mirrors were also connected with various dyonisiac-orphic rituals. The mirror was carried in front of the cult statue of Isis in processions, so that she could see her followers (Bósza 2009, 38-39).

Based on the finds, the lead mirror frames were discovered mostly in shrines: Sucidava, Orochak, Copilovtsi and Dulévo (Tudor 1959, 415-432), and in the necropolises: Intercisa, the West Cemetery of Aquincum, Viminacium, the necropolis near Mitrovačka petlja, Burgenae and Naissus (Дрча, Јеремић, Црноглавац 2012, 114, кат. бр. 99; Fitz 1957, 385-395; Крунић 2000, 17; Милошевић 
1979, 117-118, сл. 9; Милошевић 1995, 202, Т. VII, 1). The presence of lead mirrors in the graves in the Upper Moesia region is scarce. Based on the anthropological analysis of the inhumed skeletons, these were women or children, while the goods are usually chronologically insensitive. Individual finds of mirrors from the layers of the Viminacium necropolises prove that there were probably more mirrors inside the graves, but due to damage to the graves they ended up in the layer (Milovanović 2008, 121).

The presence of mirrors in the graves could be connected with their ability to reflect the sunlight, thus representing the materialisation of Sol, lighting the transition of the deceased to the afterlife (Јовановић 2000, 18). According to the old-German word scukar, a mirror is an object which retains shadow (von Franz 1995, 182). Their presence in graves could also be explained by the belief that a mirror holds the reflection of a human soul, and to free itself from the material remains, the mirror serves to keep the image, that is, the soul of the departed individual. The fact that a mirror is Venus's asset should not be forgotten. In funeral cult, Venus Funeraria secured the return for the prematurely deceased and is often identified with the old Roman goddess Venus Libitina (Јовановић 2000, 18).

The finds originating from the objects of public and private character are less numerous (forts, amphitheatres and villas; Milovanović 2008, 145-146, kat. 117; Tomović 2001, 169, Fig. 32; Величковић 1959, 55-72).

$* * *$

The most numerous are those mirrors accidentally discovered and acquired through a buy-out or given as a gift to a museum collection, while their circumstances and the contexts are often unknown. As far as we know, the greatest collection of Roman lead mirrors belongs to the Hungarian National Museum, in Budapest. It consists of 720 lead mirrors from the Roman period, only 26 being from the territory of Pannonia, and 694 from the territory of the Middle Danube region and the Carpathian basin. The accidental finds of these mirrors comprise the greatest part of the collection, as well as the ones from private collections, therefore, the precise location of where these objects were found remains unknown (Bózsa, Szabó 2014, 195). The biggest collection of lead mirrors from the territory of the Roman provinces of Serbia belongs to the National Museum in Požarevac. The collection holds 130 lead mirrors, mostly from the site of Viminacium (site Čair; Спасић 1996, 29-68). It should be noted that this collection has grown in time, especially thanks to the addition of the newly discovered mirrors from the systematic excavations of Viminacium, which have been carried out continuously for years. The Vojvodina Museum in Novi Sad also has a significant collection of these objects. The most numerous are the findings from the area of Srem, especially from the sites of Hrtkovci and Gomolava (Даутова Рушевљан 2006, 336-340; Dautova Ruševljan i Brukner 1992, 60-61; 63, T. 2, 3).

A big concentration of lead objects has been noticed at the Čair site (Viminacium), which could suggest the existence of a workshop near the settlement beside the military camp, but the types of objects (mirror frames, pendants, amulets, miniature axes, statuettes of deities and icons of Danubian horsemen) suggest another possibility - a cult place or a sanctuary (Поповић 1992a, $30,46)$. It is possible that every province had its own production centre. The workshops probably accepted one particular shape with standard or almost standard dimensions, but the possibility of the travelling plumbarii shouldn't be excluded (Крунић 2000, 13). If the decoration and style of these frames are analysed and compared to the same objects from Dacia, Thracia and Pannonia, a certain resemblance can be noted. However, the examples from Viminacium should probably form a separate group (Спасић 1996, 41-42). 


\section{$* * *$}

Representations of mirrors are found on many reliefs, wall-paintings and mosaics from the Roman time. On these, mirrors are usually represented as attributes of deities (Venus, Cupid or Hermaphroditos), being the symbol of beauty and femininity, as well as objects for everyday cosmetic/toilet use (Bózsa 2012, 38).

Round mirrors with one handle often appear on Roman tombstones. The mirror was often shown below the epigraphic field or in the gable of the stelae with various objects (a comb, a rosette, a writing tablet, shoes; Vulić, 1931, 27-28, kat. 53; 213-214, kat. 569-570). On the pediment of a stela from Singidunum, a mirror is depicted together with a pair of shoes, a writing tablet and two rosettes. The tombstone belonged to a girl only two years and eight months old (IMS I 42). On stelae and sarcophagi in Pannonia and Noricum, a special type of depictions appears - standing girls, holding mirrors above their heads or on their chests (Bózsa 2012, 38; Garbsch 1965, Tafel $1-4 ; 12-15)$. Depictions of mirrors on tombstones can be linked to a funerary cult and they can also have the role of a mediator between two worlds - the profane and the afterlife (Bósza 2012, 39; Milovanović 2008, 122).

\section{$* * *$}

Decoration of miniature lead mirror frames is often lavish and very diverse; they are mainly adorned with geometric and floral, rarely figural motifs. The most numerous are the mirrors with a circular frame and a vertical handle. These lead mirrors are primarily typical of Pannonia and the Balkan provinces, while they are very rare in the western and northern provinces of the Roman Empire (Bózsa, Szabó 2014, 198, 204).

The Rit find mirror frames have rich decoration that can be associated with certain symbolic meanings. Geometrical motifs, such as radial lines on the lead mirror frames, could be connected with the Sun rays and solar mysticism in general, which dominated the II and the III century through the widely spread cult of the god Mithras (Спасић 1996, 37, 44-45). The motif of a rhomboid with the granule could be linked to the so-called "evil eye", against which various talismans of prophylactic character were worn (Спасић-Ђурић 2008, 158-159).

The vine motif was depicted very often in the Roman period - on tombstones, utilitarian and religious objects, mosaics, frescoes, etc. (Korać 2007, 19-22; Спасић 1996, 32). On the territory of Pannonia and Moesia Superior, this motif occurs from the II century onwards. Floral motifs, such as tendrils, grapevines and grape clusters, are shown on numerous lead mirror frames from the territory of Serbia (Даутова Рушевљан 2006; 336, тип II, сл. 2/9-11; Косановић 2015, 221-222; Крунић 2000, 6-13; Milovanović 2008, 127-133, тип II, III, кат. бр. 19-59; Спасић 1996, 31-34, типови I-VI, кат. бр. 1-23). A stylised depiction of a vine on the mirror frames could be connected with the grapevine, while the granules would represent the grapes. The periodic death and rebirth of the plant symbolically represent the waking of nature, but also life itself. In this case, the grapevine could be associated with the resurrection, not only that of nature, but also of the people who strive towards immortality. With the symbolic interpretation of the grapevine, it is inevitable to mention Dionysus. The deity is born again after death, resurrects, becomes the protector of the vegetation that dies and is reborn year after year, just like the deity itself. The motif of the grapevine is present mostly on gravestones (stelae, sarcophagi), independently or in combination with other ornaments, originally as a symbol of immortality, which, over the course of time, lost that function and became a decoration of those parts of the monuments suitable to be filled with vine motifs (the frieze or the frame of the writing field; Крунић 2011, 375; Миловановић 2001, 110-111). Wall painting of late ancient and early Christian tombs also contains the motif of the vine, which has, besides symbolising immortality, become a constituent part of the heaven representations for Christians 
(Anđelković Grašar, Nikolić, Rogić 2013, 89-90; Korać 2007, 43-48; 73-74; Marijanski-Manojlović 1987, 17-32; Мирковић 1956, 53-71). The grapevine is often shown on the discs of pottery lamps, which, apart from their practical use, had a symbolic meaning in the funeral context - lighting the way to the afterlife for the deceased (Korać 1995, 151, kat. 1697; 172, kat. 2073; Крунић 2011, 374-375). The grapevine motif also occurs on pottery and toreutic vessels, and is particularly frequent in the period of the II to III century (Крунић 2011, 375).

\section{CONCLUSION}

New finds of lead mirror frames from Rit complement and confirm the already well-known and accepted opinion of scholars and experts on the cult-apotropaic character of these types of items. One cannot say with certainty that these finds form a hoard, but it is unlikely that the higher concentration of these types of items is found in one place by accident. The find location at the necropolis, as well as the frame decoration with specific symbolic motifs, indicates the funerary cult or apotropaic function of the mirrors.

The frames (Cat. Nos. 1-5) are identical in size and in all the details, so it can be suggested that they might have been made in the same workshop or even in the same mould. There are already assumptions about the existence of workshops for production of lead objects in Viminacium, so this information would stand in favour of that theory. Some of the types of these lead mirror frames have not been found in Viminacium so far. For most of the mirrors, analogies can be found in the Hungarian National Museum in Budapest.

The findings, mainly according to the finds from the nearby necropolis and from the ditch, are dated in the period of the II to III century, the period of the highest frequency of this type of finds in Roman provinces.

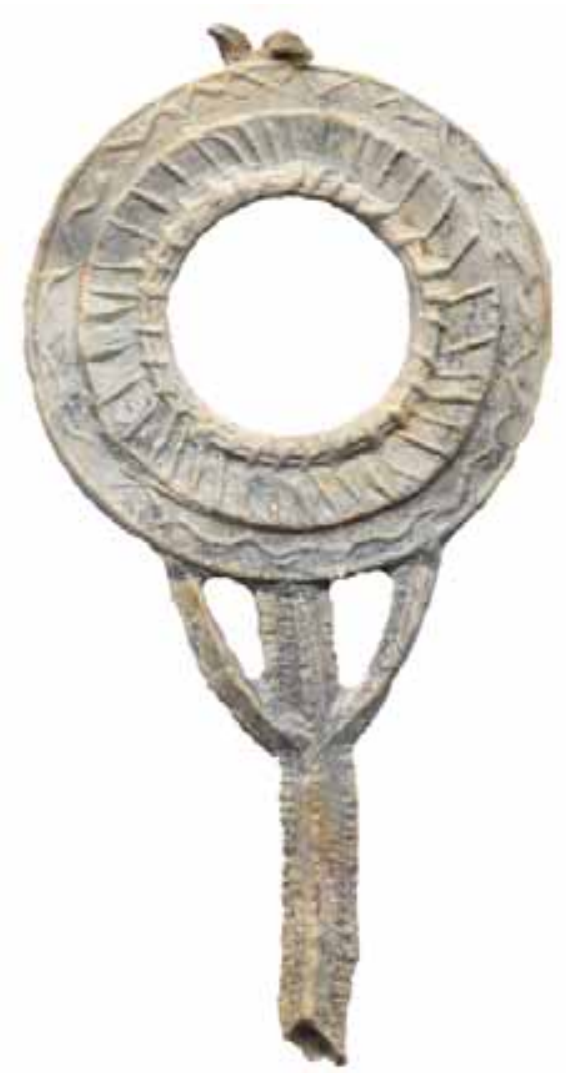

Fig. 1

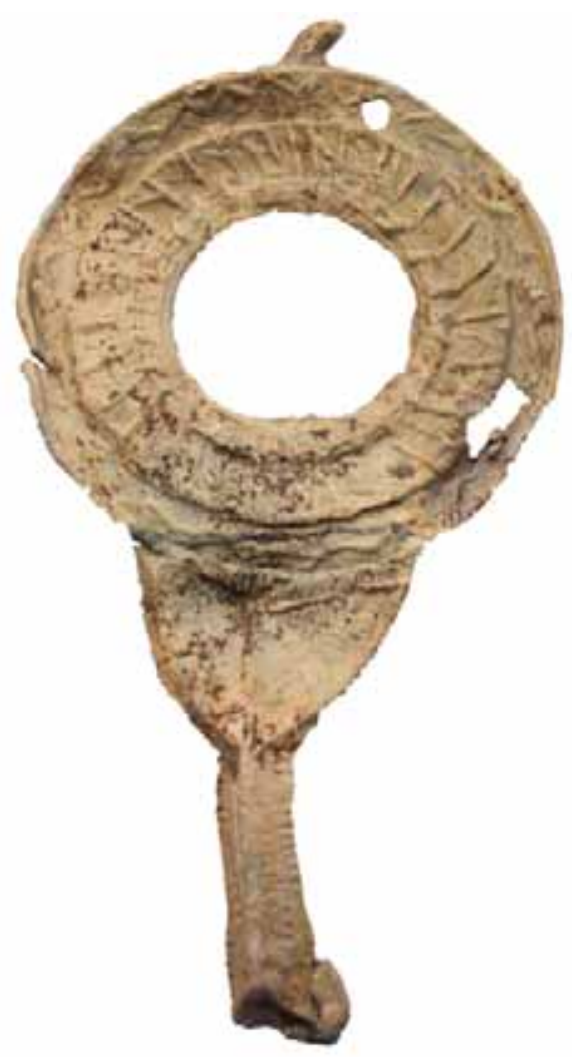

Fig. 2 


\section{CATALOGUE}

\section{Miniature mirror frame, T. I/1, fig. 1}

Documentation centre Viminacium, inv. nr. 1601. Lead, casting, bipartite mould.

Dimensions: length $-10.3 \mathrm{~cm}$; frame diameter $5.2 \mathrm{~cm}$.

The frame is divided into three uneven concentric circle sections. Two inner circles are filled with straight radial lines, while the external section is decorated with wavy (stylised zigzag) lines. On top of the frame there are the remains of leaves. The handle is strengthened with two side bars and filled with horizontal lines.

\section{Miniature mirror frame, T. I/2, fig. 2}

Documentation centre Viminacium, inv. nr. 1602. Lead, casting, bipartite mould.

Dimensions: length $-9.9 \mathrm{~cm}$; frame diameter $5.2 \mathrm{~cm}$.

Frame decoration is identical to that of the previous specimen. The top of the frame has the remains of leaves. The handle has a triangular widening at its juncture with the frame. The lower part of the handle is filled with horizontal lines.

\section{Miniature mirror frame, T. I/3, fig. 3}

Documentation centre Viminacium, inv. nr. 1607. Lead, casting, bipartite mould.

Dimensions: length $-7.2 \mathrm{~cm}$; frame diameter $5.3 \mathrm{~cm}$

Frame decoration is identical to that of the previous example. The upper part of the triangular-widened handle is preserved.

\section{Miniature mirror frame, T. I/4, fig. 4}

Documentation centre Viminacium, inv. nr. 1605. Lead, casting, bipartite mould.

Dimensions: frame diameter $-3.9 \mathrm{~cm}$

Frame decoration is identical to that of the previous specimen. The top of the frame is decorated with two leaves. The handle is not preserved.

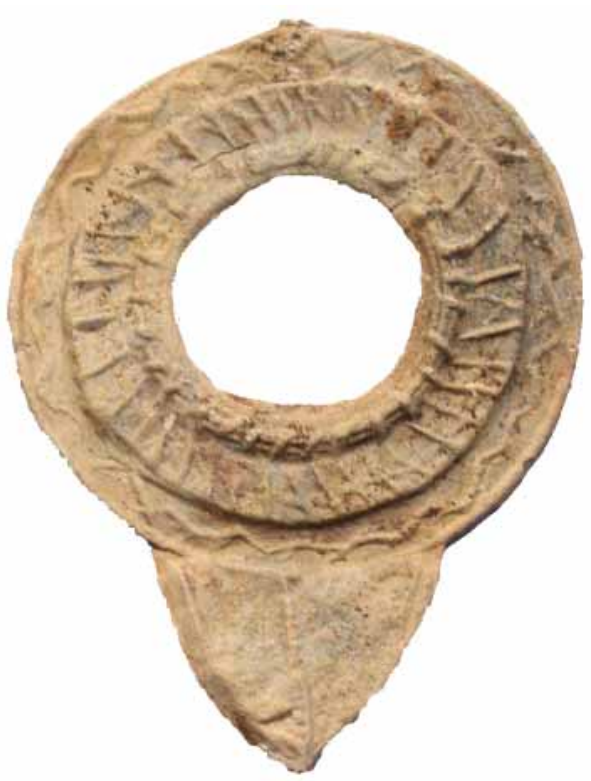

Fig. 3

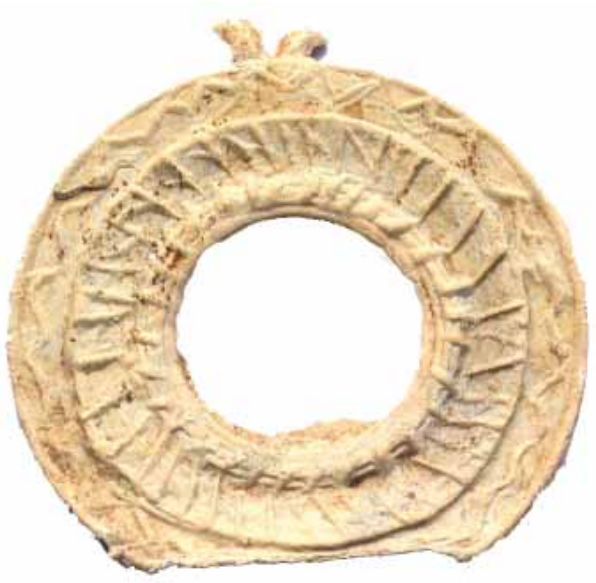

Fig. 4

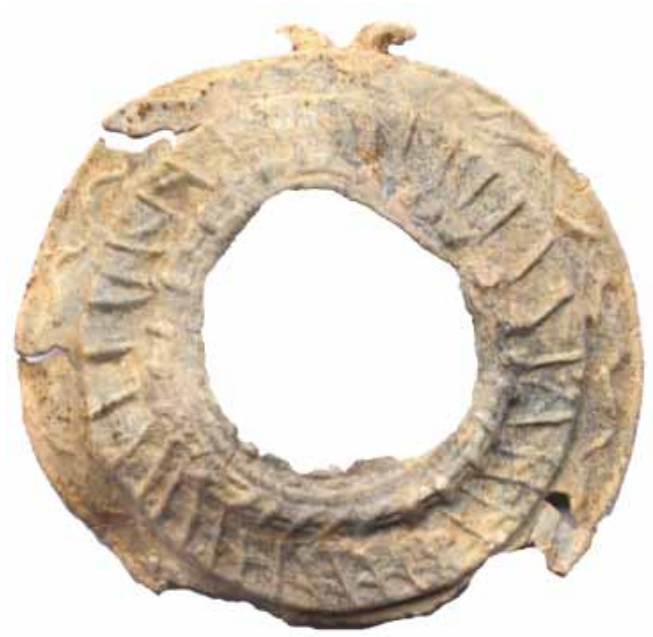

Fig. 5 


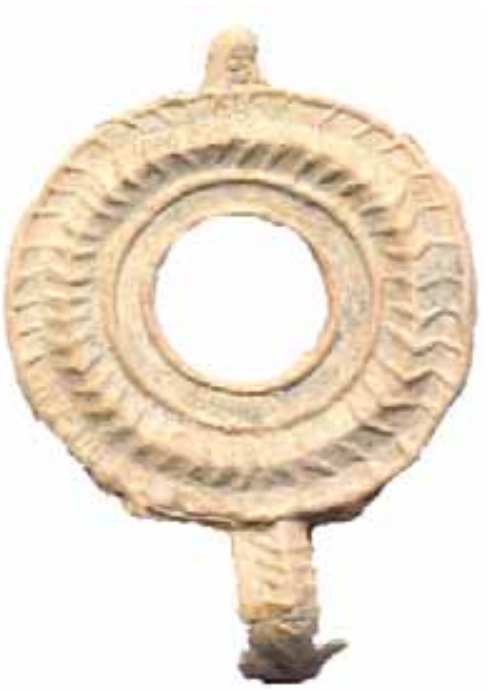

Fig. 6

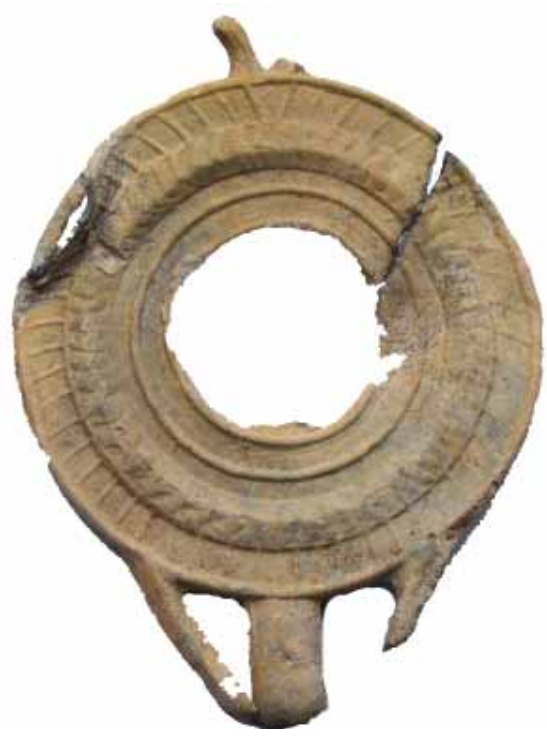

Fig. 7

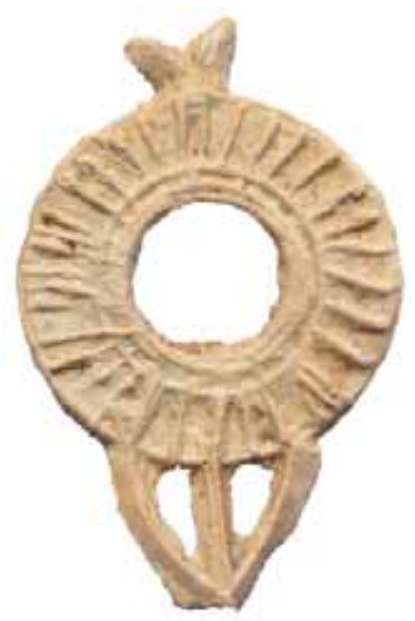

Miniature lead-mirror frame, T. I/5, fig. 5

Documentation centre Viminacium, inv. nr. 1611a. Lead, casting, bipartite mould.

Dimensions: frame diameter $-5.2 \mathrm{~cm}$.

Frame decoration is identical to that of the previous example. The top of the frame is decorated with two leaves. The handle is not preserved.

\section{Miniature lead-mirror frame, T. I/6, fig. 6}

Documentation centre Viminacium, inv. nr. $1611 \mathrm{~b}$. Lead, casting, bipartite mould.

Dimensions: length $-6.5 \mathrm{~cm}$; frame diameter $4.4 \mathrm{~cm}$.

The frame is divided into four unequal concentric circular sections. An empty inner circle is by the glass hole and three panels with alternately directed, angled radial lines are next to it. At the top of the frame, in the direction of the handle, there are the remains of leaves. The fragmented vertical handle is decorated with a fish-bone pattern.

\section{Miniature lead-mirror frame, T. I/7, fig. 7}

Documentation centre Viminacium, inv. nr. 1612. Lead, casting, bipartite mould.

Dimensions: length $-5.8 \mathrm{~cm}$; frame diameter $4.3 \mathrm{~cm}$

The fragmented frame is decorated with radial lines around the outer edge and a fish-bone motif in the middle section; the empty inner circle is by the glass hole. On the top of the frame there are the remains of leaves. Only the upper part of the handle with two side bars is preserved.

\section{Miniature lead-mirror frame, T. I/8, fig. 8}

Documentation centre Viminacium, inv. nr. 1606. Lead, casting, bipartite mould.

Dimensions: length $-6.0 \mathrm{~cm}$; frame diameter $3.8 \mathrm{~cm}$.

The frame is decorated with straight radial lines. On the top of the frame there are two leaves. The upper part of the handle with two side bars is preserved.

Fig. 8 
Miniature lead-mirror frame, T. I/9, fig. 9

Documentation centre Viminacium, inv. nr. 1603.

Lead, casting, bipartite mould.

Dimensions: frame diameter $-3.8 \mathrm{~cm}$.

The frame is decorated with floral motifs. Relief granules are arranged around the glass hole and along the outer edge of the frame, while the middle section is filled with a spiral vine with leaves and granules. The handle is not preserved.

\section{Miniature lead-mirror frame, T. I/10, fig. 10}

Documentation centre Viminacium, inv. nr. 1608. Lead, casting, bipartite mould.

Dimensions: frame diameter $-3.8 \mathrm{~cm}$

Frame decoration is identical to that of the previous specimen. The top of the frame has the remains of leaves. The handle is not preserved.

\section{Miniature lead-mirror frame, T. I/11, fig. 11}

Documentation centre Viminacium, inv. nr. 1604. Lead, casting, bipartite mould.

Dimensions: length $-7.7 \mathrm{~cm}$; frame diameter $3.9 \mathrm{~cm}$.

The frame is decorated with a combination of geometrical motifs and granules. The adornment consists of alternately distributed relief circles with granules (two) and rhomboids (three) that contain granules in the middle; the space between the rhomboids and circles is also filled with single granules. The bottom of the frame is separated from the rest by a semi-circular relief line, along which two ornaments consisting of three semi-circles with granules are arranged. The handle has horizontal and zigzag relief lines with granules between them; two symmetrical volute-like widening with a circle and granules are set half way along the handle. There are two leaves with a small circle between them in the direction of the handle, on the top of the frame.

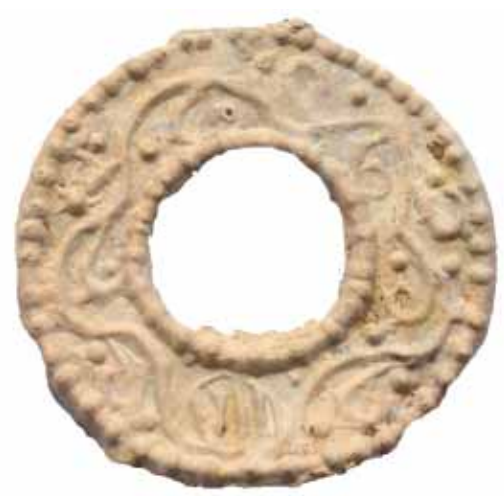

Fig. 9

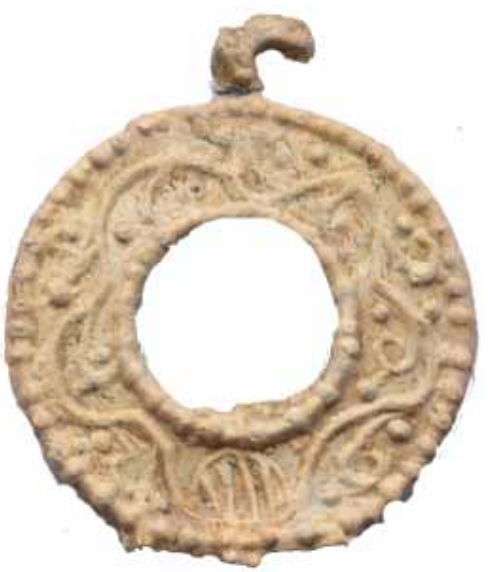

Fig. 10

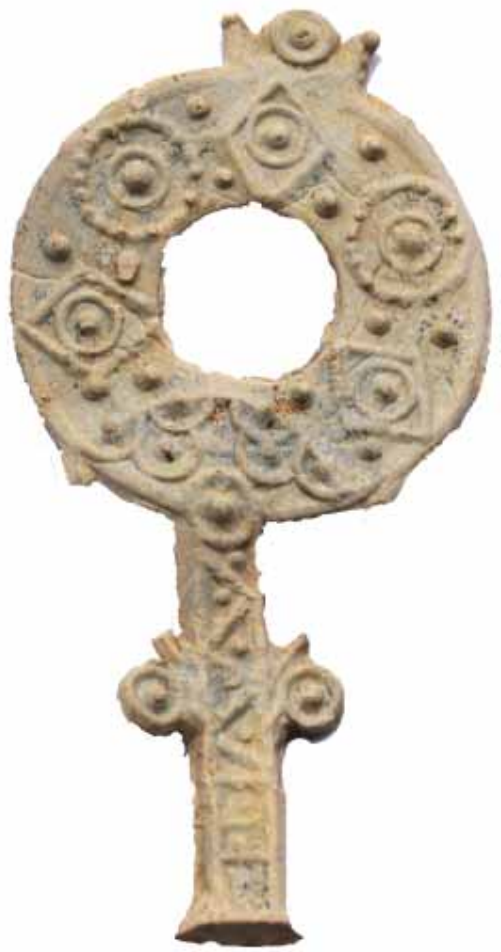

Fig. 11 


\section{BIBLIOGRAPHY}

Anđelković Grašar, J., Nikolić, E. i Rogić, D. 2013

„Tomb with Cupids“ from Viminacium: a contribution to research of construction, iconography and style, „Гробница са купидонима“ из Виминацијума: Прилог проучавању конструкције, иконографије и стила, Старинар LXIII (н. с.): 73-100.

Baratta, G. 2009a

Uno specchietto in piombo da Urbs Salvia. Picus 29: 67-74.

\section{Baratta, G. 2009b}

La bella e lo specchio: alcune iscrizioni Greche su specchietti in piombo. in: Estudios de Epigrafia Griega La Laguna:427-454, A. Martínez Fernandez (ed.). La Laguna.

Чершков, Т., Јеремић, Г. и Вуловић, Д. 2014 О једној занимљивој гробној целини из Јагодин мале, Ниш (Naissus), Зборник Народног музеја у Ниму 23. Ниш: 35-64.

Bózsa, A. 2012

Tükör mint szimbólum? In: Firkák II-Fiatal Római Koros Kutatók II. konferenciakötete. Győr: Mursella Régészeti Egyesület: 31-45.

Bózsa, A., Szabó, Á. 2013

„Ajándék a szépnek!” A Magyar Nemzeti Múzeum Római Gyüjteményének 'ólomtükrei'. Budapest: Magyar Nemzeti Múzeum.

Bózsa, A., Szabó, Á. 2014.

Tükör vagy nem tükör? In: Firkák III-Fiatal Római Koros Kutatók III. konferenciakötete. Szombathely: Savaria Múzeum: 195-204.

Даутова Рушевљан, В. 2006

Римски предмети од олова из Срема. Гласник Српског археолошког друштва 22: 333-352.
Dautova Ruševljan, V. i Brukner, O. 1992

Gomolava: rimski period. Gomolava 3. Novi Sad:

Vojvođanski muzej.

Дрча, С., Јеремић, Г. и Црноглавац, В. 2012

Јагодин мала, касноантичка некропола (каталог изложбе), Ниш.

Fitz, J. 1957

Bleigegenstände. 384-397. In Intercisa II: (Dunapentele) Geschichte der Stadt in der Römerzeit, M. R. Alföldi et al. (eds.) Budapest: Akadémiai Kiadó.

Garbsch, J. 1965

Die Horisch-pannonische Frauentracht im 1. und 2. Jahrhundert, München.

\section{Јеремић, Г. 2014}

Оквир огледала. 114. у: Јагодин мала, касноантичка некропола, С. Поповић (ур.). Ниш: Народни музеј.

\section{Јовановић, А. 2000}

Нумизматичке белешке уз култ подунавских коњаника. Нумизматичар 21 (1998): 11-27.

Korać, M. 2007

Slikarstvo Viminacijuma, The Paintings of Viminacium, Beograd.

\section{Korać, M. 1995}

Žišci sa teritorije Viminacijuma, Doktorska disertacija, Filozofski fakultet, Univerzitet $\mathrm{u}$ Beogradu.

Kouzov, C. 2002

Lead Roman Mirrors in Varna Archaeological Museum. Archaeologia Bulgarica VI. 3. Sofia: 63-99.

Крунић, С. 2000

Римски медицински, фармацеутски и козметички инструменти са територије Горње 
Мезије, Докторска дисертација, Филозофски факултет, Универзитет у Београду.

\section{Крунић, С. 2011}

Античке светиљке из Музеја града Београда и начини илуминачије у Сингидунуму од I до средине V века. Београд: Музеј града Београда.

\section{Marijanski-Manojlović, M. 1987}

Римска некропола код Бешке у Срему, Нови Сад.

\section{Миловановић, Б. 2001}

Вегетабилни мотиви на надгробним споменицима из Виминацијума, Viminacivm 12: 109-134.

\section{Milovanović, B. 2008}

Rimsko olovo u Srbiji - eksploatacija, proizvodnja i upotreba, Doktorska disertacija, Filozofski fakultet, Univerzitet u Beogradu.

Милошевић, П. 1979

Три ранохришћанска гробна објекта у Срему, Рад Војвођанских музеја 25: 115-120.

Милошевић, П. 1995

Римска некропола на излазници митровачке петље (26), у: Археолошка истраживања дуж аутопута кроз Срем, Нови Сад.

\section{Мирковић, Л. 1956}

Старохришћанска гробница у Нишу, Старинар V-VI (н. с.): 53-71.

\section{Mirković, M. i Dušanić, S. 1976}

Inscriptiones de la Mésie Supérieure, Vol I, Singidunum et le Nord-Ouest de la province, Beograd.

\section{Németh, G, and Szabó, Á. 2010}

To a beautiful soul. Inscriptions on lead mirrors. Acta classica Univ. Scient. Debrecen 46. Debrecen: 101-113.

\section{Поповић, И. 1992}

Радионица оловних предмета или светилишта култа подунавских коњаника у Виминацијуму. Viminacium 7: 29-56.

\section{Спасић, Д. 1996}

Античка оловна огледала из Народног музеја у Пожаревцу. Viminacium 10 (1995-1996): 29-68.

Спасић-Ђурић, Д. 2008

Фалички мотиви из Виминацијума, Гласник САД 24: 121-174.

\section{Tomović, M. 2001}

Kraku Lu Jordan and Gold Mining and Matallurgy in Antiquity, Старинар L: 155-185.

\section{Tudor, D. 1959}

Le dépot de miroirs de verre double de plomb trouve á Sucidava. Dacia (n.s.) 3: 415-432.

\section{Величковић, М. 1959}

Оловни оквири античких стаклених огледала из Народног музеја. Зборник Народног музеја 2-2 (1958-1959). Београд: 55-72.

\section{Von Franz, M-L. 1995}

Projection and Re-Collection in Jungian Psychology: Reflections of the Soul. Peru: Open Court Publishing Company. 
REZIME

NOVI NALAZ OKVIRA OGLEDALA OD OLOVA IZ VIMINACIJUMA (LOKACIJA RIT)

KLJUČNE REČI: OLOVO, MINIJATURNI OKVIRI OGLEDALA, RIT, VIMINACIUM, PREDMETI APOTROPEJSKE NAMENE.

Tokom zaštitnih arheoloških iskopavanja u Viminacijumu (lokacija Rit) tokom 2015. godine otkriveno je jedanaest okvira ogledala od olova. Lokalitet je bio ugrožen širenjem površinskog kopa Drmno, a nalazi se severoistočno od užeg gradskog jezgra Viminacijuma. Do sada su na ovoj lokaciji istražene četiri vile, kao i delovi nekropola. Skorašnjim arheološkim istraživanjima je utvrđeno da su ovi rezidencijalni objekti podignuti tokom III veka, i da su praćeni nekropolom koja se širi ka severoistoku, verovatno duž puta od Viminacijuma ka Lederati.

Okviri su pronađeni u rovu za koji se pretpostavlja da je prvobitno služio pri drenaži terena, a kasnije za odbacivanje materijala prilikom čišćenja nekropole, a mogao je predstavljati i granicu nekropole. Pored okvira ogledala, ulomaka različitih keramičkih posuda i životinjskih kostiju, u rovu je pronađena i bronzana igla sa glavom u vidu sekire, dno keramičkog žiška sa pečatom NERI i novac od bronze iz sredine III veka (Valerianus, Provincia Dacia).

Svih jedanaest primeraka minijaturnih ogledala od olova liveno je u dvodelnom kalupu. Svi primerci imaju kružni okvir sa listićima na vrhu. Pojedini primerci imaju u donjem delu očuvanu vertikalnu dršku, koja može biti trouglasto proširena ili ojačana bočnim krakovima. Staklo nije očuvano ni kod jednog primerka, a na njihovoj poleđini, oko otvora za staklo, nalazi se reljefna kružnica.

Prema dekoraciji, ova ogledala se mogu svrstati u pet grupa. Prvoj grupi pripadaju ogledala čiji su okviri podeljeni na tri koncentrična kružna polja, od kojih su dva ispunjena radijalnim lini- jama, a jedno, spoljno polje, ukrašeno je talasastom (stilizovanom cik-cak) linijom (kat. br. 1-5). Jedan okvir ogledala (kat. br. 6) je kružnicama podeljen na tri prstenaste zone sa kosim radijalima usmerenim u suprotnom smeru. $\mathrm{U}$ isti tip bi se mogao svrstati i okvir ukrašen motivom riblje kosti u sredini i radijalnim linijama oko spoljne ivice (kat. br. 7). Ogledala (kat. br. 8) ima jednostavno ukrašen okvir izveden reljefnim radijalnim linijama. Dva okvira ogledala su ukrašena vegetabilnim motivima (kat. br. 9-10), odnosno spiralnom lozom i granulama. Posebno je zanimljiv nalaz okvira koji je ukrašen naizmenično raspoređenim reljefnim krugovima i rombovima u kojima su kružnice sa granulom u sredini (kat. br. 11). Prostor između rombova i krugova je ispunjen pojedinačnim granulama. Donji deo okvira i drška, takođe su ukrašeni kombinacijom geometrijskih motiva i granula.

\section{$* * *$}

Pojedini primerci opisani u radu (kat. 1-5; 11) do sada nisu pronalaženi na teritoriji Viminacijuma i jedine zasada poznate analogije potiču iz Nacionalnog muzeja u Budimpešti. Nalazi su datovani u period II-III veka. Moguće je da nekoliko ogledala identičnih u dimenzijama i svim detaljima (kat. 1-5) potiče iz iste radionice (ili čak iz istog kalupa), koja se na osnovu brojnih nalaza minijaturnih ogledala od olova može locirati u Viminacijumu.

Novi nalazi olovnih ogledala iz Rita upotpunjuju i potvrđuju već dobro poznato i prihvaćeno mišljenje stručne javnosti o kultno-apotropejskom karakteru ove vrste predmeta. Moguće je da nalazi opisani u radu potiču iz grobova i da su u rov dospeli čišćenjem nekropole koja je locirana u neposrednoj blizini. Ne treba isključiti ni mogućnost da se radi o ostavi, s obzirom na to da su svi okviri pronađeni na površini od $1 \mathrm{~m}^{2}$. Na kultno-apotropejsku funkciju ovih primeraka mogu ukazivati i dekorativni motivi njihovih okvira. 

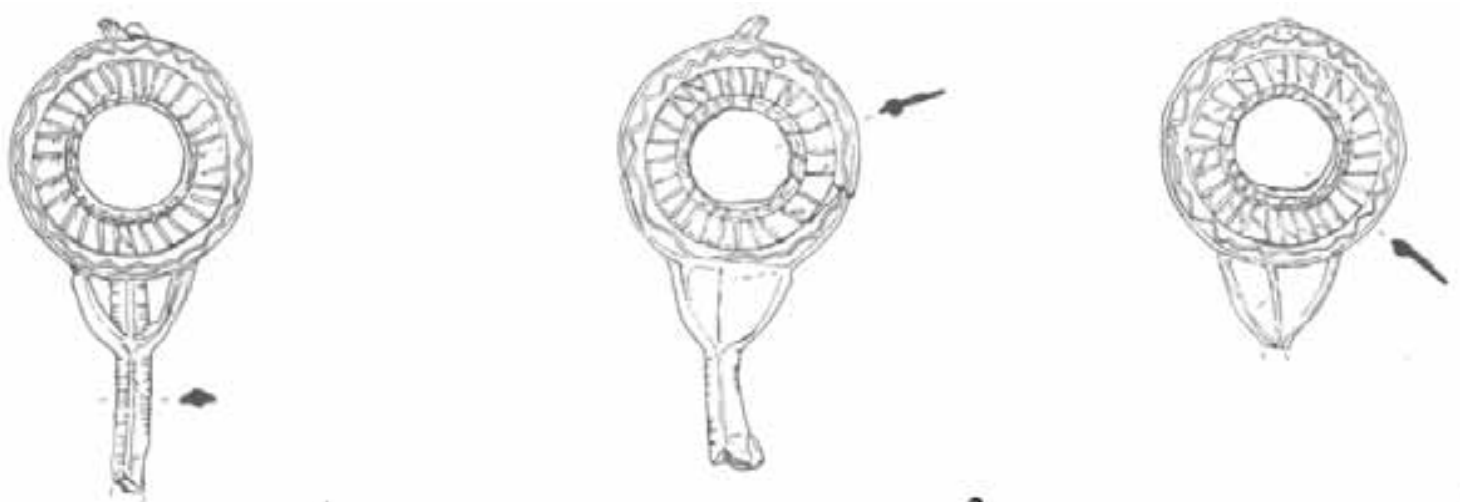

1

2
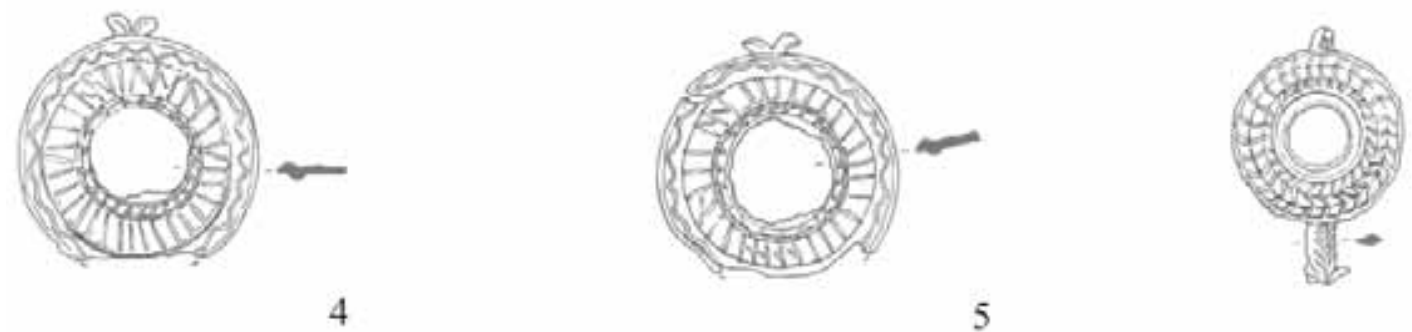

4

5
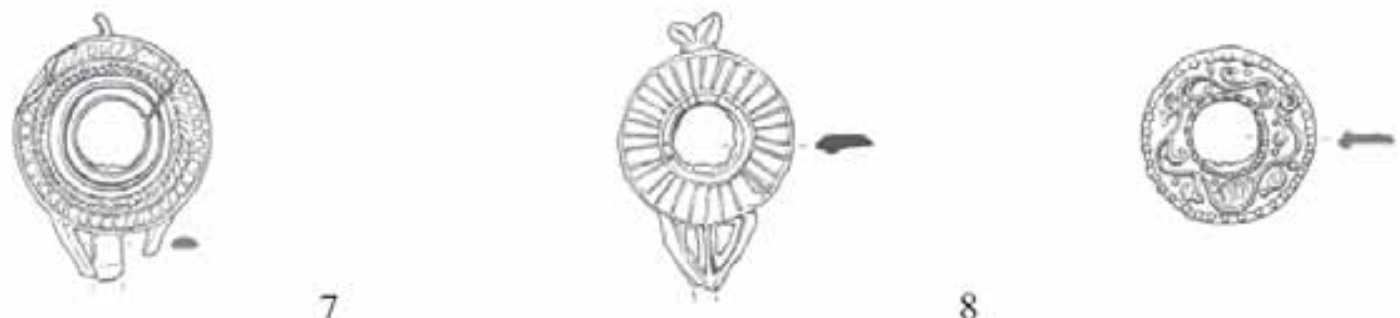

7

8

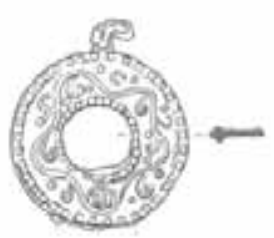

10

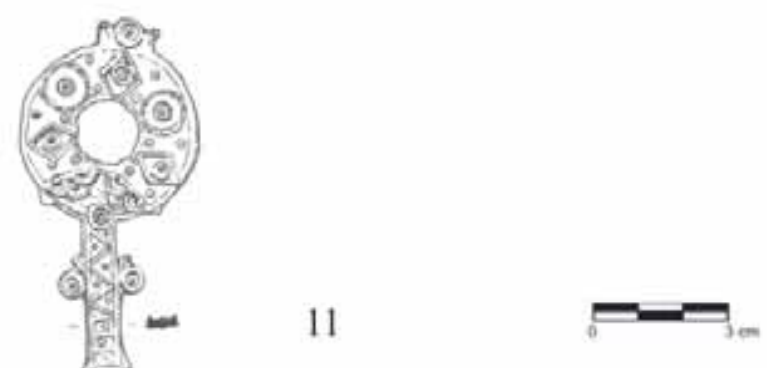

Table I. Lead mirror frames from Viminacium (the Rit site) (drawings by E. Dobrić and M. Ranisavljev) 